\title{
Occupation and five cancers: a case-control study using death certificates
}

\author{
C MAGNANI, D COGGON, C OSMOND, E D ACHESON \\ From the MRC Environmental Epidemiology Unit, University of Southampton, Southampton General Hospital, \\ Southampton SO9 $4 X Y, U K$
}

\begin{abstract}
A case-control approach has been used to examine mortality from five cancersoesophagus, pancreas, cutaneous melanoma, kidney, and brain-among young and middle aged men resident in three English counties. The areas studied were chosen because they include major centres of chemical manufacture. By combining data from 20 years it was possible to look at local industries with greater statistical power than is possible using routine national statistics. Each case was matched with up to four controls of similar age who died in the same year from other causes. The occupations and industries recorded on death certificates were coded to standard classifications and risk estimates derived for each job category. Where positive associations were found the records of the cases concerned were examined in greater detail to see whether the risk was limited to specific combinations of occupation and industry. The most interesting findings to emerge were risks of brain cancer associated with the production of meat and fish products (relative risk $(R R)=9 \cdot 7$, $95 \%$ confidence interval $(\mathrm{CI}) 2 \cdot 6-36 \cdot 8)$ and with mineral oil refining $(\mathrm{RR}=2 \cdot 9, \mathrm{CI} 1 \cdot 2-7 \cdot 0)$, and a cluster of four deaths from melanoma among refinery workers $(R R=16 \cdot 0, \mathrm{CI} 1 \cdot 8-143 \cdot 2)$. A job-exposure matrix was applied to the data but gave no strong indications of further disease associations. Local analyses of occupational mortality such as this can usefully supplement national statistics.
\end{abstract}

Occupational mortality statistics for England and Wales have been published since 1855 and are a well established method of monitoring industrial health hazards. Their value is limited, however, by the poor specificity of many of the occupational categories analysed. A fitter in a chemical works is exposed to known and potential hazards quite different from a fitter in a textile factory but both are classed together in the conventional method of analysis used by the Registrar General. Possibly other methods of examining occupational mortality data might shed light on hitherto unrecognised problems.

We have used the case-control approach to look at five cancers - oesophagus, pancreas, cutaneous melanoma, kidney, and brain-for which the a priori evidence of occupational aetiology was relatively limited. ${ }^{1-3}$ Our aim was to generate clues to new occupational risks of cancer and our method differed from that of most previous mortality analyses in several important respects. Firstly, we concentrated on deaths occurring in geographically localised areas selected because they are centres of certain "suspect"

Accepted 24 November 1986 industries, in particular chemical manufacture. This meant that we could look at associations between cancer and employment in these industries with greater statistical efficiency. Secondly, we included information about industry as well as occupation in our analysis and, thirdly, we restricted our attention to cancers occurring before the age of 55 . The advantage of focusing on the younger age groups is that occupational data from death certificates are likely to be more complete and certified causes of death more accurate. Also, it appears that for certain known industrial carcinogens - for example, bischloromethyl ether ${ }^{4}$ - the risk of cancer is highest and therefore most easily demonstrable in young people.

\section{Material and methods}

The area studied comprised the pre-1974 local authorities listed in table 1 , and is roughly equivalent to the modern counties of Cleveland, Humberside, and Cheshire together with the Wirral district of Merseyside. Table 2 shows the distribution of industry in this area at the time of the 1971 census and contrasts the pattern with that for England and Wales as a 
Table 1 Local authority areas studied

\begin{tabular}{|c|c|c|}
\hline $\begin{array}{l}\text { Cleveland } \\
\text { Hartlepool CB } \\
\text { Teesside CB } \\
\text { Guisborough UD }\end{array}$ & $\begin{array}{l}\text { Loftus UD } \\
\text { Saltburn and Marske-by-the-Sea UD } \\
\text { Skelton and Brotton UD }\end{array}$ & Stockton RD \\
\hline $\begin{array}{l}\text { Humberside } \\
\text { Kingston-upon-Hull CB } \\
\text { Grimsby CB } \\
\text { Beverley MB } \\
\text { Cleethorpes MB } \\
\text { Goole MB } \\
\text { Hedon MB } \\
\text { Scunthorpe MB }\end{array}$ & $\begin{array}{l}\text { Barton-upon-Humber UD } \\
\text { Brigg UD } \\
\text { Haltemprice UD } \\
\text { Hornsea UD } \\
\text { Withernsea UD } \\
\text { Beverley RD }\end{array}$ & $\begin{array}{l}\text { Glanford Brigg RD } \\
\text { Goole RD } \\
\text { Grimsby RD } \\
\text { Holderness RD } \\
\text { Howden RD } \\
\text { Isle of Axholme RD }\end{array}$ \\
\hline $\begin{array}{l}\text { Cheshire and the Wirral } \\
\text { Birkenhead CB } \\
\text { Chester CB } \\
\text { Wallasey CB } \\
\text { Warrington CB } \\
\text { Bebington MB } \\
\text { Congleton MB } \\
\text { Crewe MB } \\
\text { Ellesmere Port MB } \\
\text { Macclesfield MB } \\
\text { Widnes MB }\end{array}$ & $\begin{array}{l}\text { Alsager UD } \\
\text { Bollington UD } \\
\text { Hoylake UD } \\
\text { Lymm UD } \\
\text { Middlewich UD } \\
\text { Nantwich UD } \\
\text { Neston UD, } \\
\text { Northwich UD } \\
\text { Runcorn UD } \\
\text { Sandbach UD }\end{array}$ & $\begin{array}{l}\text { Winsford UD } \\
\text { Wirral UD } \\
\text { Chester RD } \\
\text { Congleton RD } \\
\text { Macclesfield RD } \\
\text { Nantwich RD } \\
\text { Northwich RD } \\
\text { Runcorn RD } \\
\text { Tarvin RD } \\
\text { Warrington RD }\end{array}$ \\
\hline
\end{tabular}

whole. Almost $10 \%$ of the male workforce yas employed in chemical production, in particular general chemicals $(6 \cdot 4 \%)$, soap and detergents $(0.8 \%)$, fertilisers $(0 \cdot 6 \%)$, synthetic resins and plastics $(0 \cdot 6 \%)$,

Table 2 Proportion of working men employed in different industrial orders in the study area and in England and Wales. Data from the 1971 census

\begin{tabular}{|c|c|c|}
\hline \multirow[b]{2}{*}{ Industry } & \multicolumn{2}{|c|}{$\begin{array}{l}\text { Proportion of } \\
\text { working men employed (\%) }\end{array}$} \\
\hline & Study area & $\begin{array}{l}\text { England } \\
\text { and Wales }\end{array}$ \\
\hline Agriculture and horticulture & $3 \cdot 5$ & $3 \cdot 3$ \\
\hline Mining and quarrying & 0.4 & $2 \cdot 5$ \\
\hline Food, drink, and tobacco & $3 \cdot 5$ & $2 \cdot 8$ \\
\hline Coal and petroleum products & $1 \cdot 2$ & 0.4 \\
\hline Chemicals and allied industries & 9.9 & $2 \cdot 2$ \\
\hline Metal manufacture & $7 \cdot 8$ & $3 \cdot 2$ \\
\hline Mechanical engineering & $4 \cdot 6$ & $6 \cdot 2$ \\
\hline Instrument engineering & $0 \cdot 2$ & 0.6 \\
\hline Electrical engineering & 1.6 & $3 \cdot 6$ \\
\hline Shipbuilding and marine engineering & $2 \cdot 7$ & $1 \cdot 0$ \\
\hline Vehicles & $5 \cdot 4$ & $4 \cdot 8$ \\
\hline Metal goods not elsewhere specified & $2 \cdot 1$ & 2.9 \\
\hline Textiles & $1 \cdot 3$ & $2 \cdot 1$ \\
\hline Leather, leather goods, and fur & $0 \cdot 3$ & $0 \cdot 2$ \\
\hline Clothing and footwear & 0.4 & $0 . \overline{9}$ \\
\hline Bricks, pottery, glass, cement, etc & 1.6 & 1.6 \\
\hline Timber, furniture, etc & $1 \cdot 3$ & 1.6 \\
\hline Paper, printing, and publishing & $2 \cdot 0$ & $2 \cdot 8$ \\
\hline Other manufacturing industries & 0.6 & $1 \cdot 4$ \\
\hline Construction & $10 \cdot 1$ & $10 \cdot 3$ \\
\hline Gas, electricity, and water & 1.9 & $2 \cdot 0$ \\
\hline Transport and communication & $10 \cdot 2$ & 8.6 \\
\hline Distributive trades & $8 \cdot 7$ & 9.7 \\
\hline \multicolumn{3}{|l|}{ Insurance, banking, finance, and } \\
\hline business services & $2 \cdot 1$ & $3 \cdot 2$ \\
\hline Professional and scientific services & $5 \cdot 6$ & $6 . \overline{9}$ \\
\hline Miscellaneous services & $5 \cdot 3$ & $7 \cdot 2$ \\
\hline Public administration and defence & $5 \cdot 4$ & $7 \cdot \overline{4}$ \\
\hline
\end{tabular}

and dyestuffs and pigments (0.6\%). Other important industries in the study area were metal manufacture $(7.8 \%)$, vehicle production $(5.4 \%)$, and mechanical engineering $(4 \cdot 6 \%)$.

The cases were men aged $18-54$ and resident in the $\vec{\bullet}$ study area who died from one of the five cances under investigation during the periods 1959-63 an 1965-79. (Data from 1964 were not available.) Eac case was assigned two controls who had died in the same year from other causes and who were matched to the case for sex, county of residence (as defined in table 1), and as closely as possible for age at death. A second set of controls was selected according to similar criteria but with residence matched by local authority instead of by county. Controls were rejected if their age at death differed from that of the case by more than five years, and because of this a few cases were left with fewer than four controls. The selection of cases and controls was carried out independently for each of the five cancers, and a subject included as a case for one disease was eligible to serve as a control $\delta$ for each of the other four. A preliminary analysis showed no important differences between the results 0 obtained with the two control groups separately, and in this presentation the two sets of controls have been amalgamated.

Copies of the relevant death certificates were of provided by the Office of Population Censuses and $N$ Surveys (OPCS), and the occupations and industries $N$ recorded thereon were coded according to the Registrar General's 1966 Classification of Occupations ${ }^{5}$ and 1968 Classification of Industries. ${ }^{6} \mathrm{~A}$ job- $\stackrel{\odot}{\odot}$ exposure matrix was used to further classify subjects according to their potential exposure to 49 chemical, 
Table 3 Numbers of cases and controls and distribution of causes of death among the controls

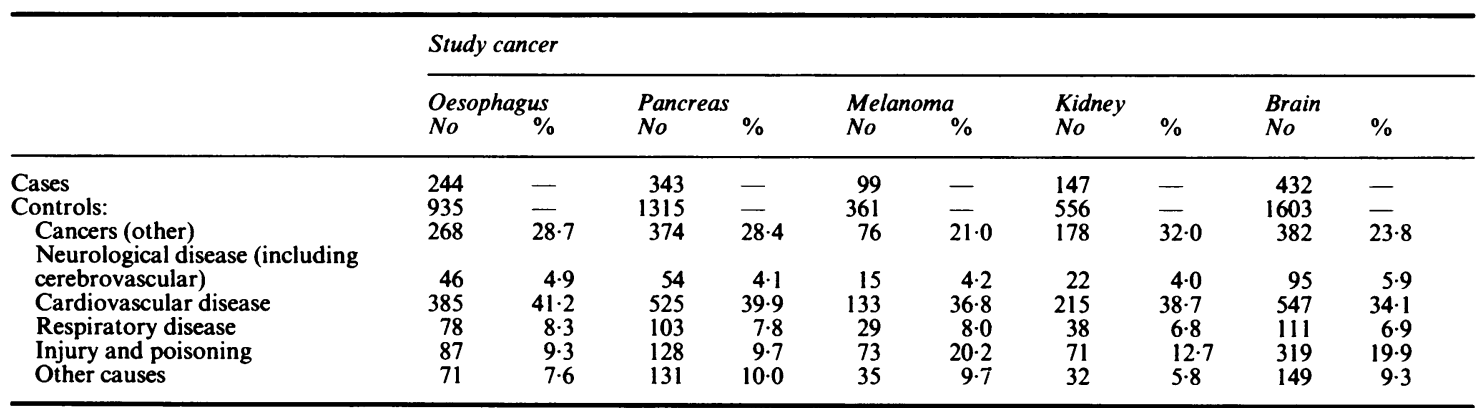

physical, and biological agents. ${ }^{7}$ Associations with cancer were examined and maximum likelihood estimates of relative risk were derived with test based $95 \%$ confidence intervals according to the method for matched data with a variable number of controls. ${ }^{8}$

\section{Results}

Table 3 shows the number of cases and controls for each of the five cancers studied and summarises the causes of death in the control groups.

In our analysis of cancer by industry and occupation we looked first at associations with the broad industrial and occupational orders defined by the Registrar General (tables 4 and 5). As indicated in the tables, industry and, to a lesser extent, occupation were not always adequately recorded on death certificates. For all five cancers information was more complete for cases than controls.

able 4 Associations between cancer and industrial orders: relative risks $(R R)$ and $95 \%$ confidence intervals (CI)

\begin{tabular}{|c|c|c|c|c|c|c|c|c|c|c|}
\hline & \multicolumn{10}{|c|}{ Cancer site/type } \\
\hline & \multicolumn{2}{|c|}{ Oesophagus } & \multicolumn{2}{|c|}{ Pancreas } & \multicolumn{2}{|c|}{ Melanoma } & \multicolumn{2}{|c|}{ Kidney } & \multicolumn{2}{|c|}{ Brain } \\
\hline & $R R$ & $C I$ & $\boldsymbol{R} R$ & $C I$ & $R R$ & $C I$ & $R R$ & $C I$ & $R R$ & $C I$ \\
\hline griculture, forestry, fishing & $1 \cdot 1$ & $(0 \cdot 4-2 \cdot 8)$ & 0.8 & $(0.4-1.8)$ & 0.7 & $(0 \cdot 2-2 \cdot 5)$ & $1 \cdot 5$ & $(0.6-3.8)$ & $1 \cdot 0$ & $(0.5-1.8)$ \\
\hline lining and quarrying & \multirow{8}{*}{\multicolumn{2}{|c|}{\begin{tabular}{ll}
$(0 \mathrm{ca} v$ & $v$ co $)$ \\
0.4 & $(0 \cdot 1-1 \cdot 3)$ \\
1.8 & $(0 \cdot 2-20 \cdot 1)$ \\
1.1 & $(0.6-1 \cdot 9)$ \\
0.9 & $(0.5-1 \cdot 7)$ \\
1.0 & $(0.5-2 \cdot 3)$ \\
\multicolumn{2}{l}{$(0 \mathrm{ca} v 5 \mathrm{co})$}
\end{tabular}}} & $0 \cdot 5$ & $(0 \cdot 1-4 \cdot 5)$ & & & 0.9 & $(0 \cdot 1-8 \cdot 4)$ & $1 \cdot 3$ & $(0 \cdot 3-4 \cdot 9)$ \\
\hline ood, drink, and tobacco & & & $1 \cdot 5$ & $(0 \cdot 8-2 \cdot 7)$ & 0.4 & $(0 \cdot 1-3 \cdot 4)$ & 0.6 & $(0 \cdot 2-1 \cdot 9)$ & $2 \cdot 6$ & $(1 \cdot 5-4 \cdot 5)$ \\
\hline oal and petroleum products & & & $1 \cdot 8$ & $(0 \cdot 7-4 \cdot 7)$ & $8 \cdot 0$ & $(1 \cdot 5-43 \cdot 7)$ & $1 \cdot 3$ & $(0 \cdot 3-5 \cdot 1)$ & $3 \cdot 5$ & $(1 \cdot 5-8 \cdot 1)$ \\
\hline 'hemicals and allied industries & & & 1.4 & $(0 \cdot 9-2 \cdot 3)$ & $1 \cdot 5$ & $(0.6-3 \cdot 8)$ & $1 \cdot 3$ & $(0.6-2.6)$ & $1 \cdot 1$ & $(0 \cdot 7-1 \cdot 7)$ \\
\hline Ietal manufacture & & & 0.8 & $(0 \cdot 5-1 \cdot 4)$ & $1 \cdot 2$ & $(0.4-3.0)$ & 1.0 & $(0.5-1 \cdot 9)$ & $1 \cdot 2$ & $(0.8-1.8)$ \\
\hline Iechanical engineering & & & 0.9 & $(0.4-1.9)$ & $0 . \overline{3}$ & $(0 \cdot 0-2 \cdot 5)$ & 1.9 & $(0 \cdot 6-5 \cdot 5)$ & 1.4 & $(0 \cdot 8-2 \cdot 6)$ \\
\hline istrument engineering & & & $2 \cdot 0$ & $(0 \cdot 2-22 \cdot 1)$ & \multirow{2}{*}{\multicolumn{2}{|c|}{$(0 \mathrm{ca} v 1 \mathrm{co})$}} & \multirow{2}{*}{\multicolumn{2}{|c|}{$\begin{array}{l}(0 \mathrm{ca} v 1 \mathrm{co}) \\
15 \cdot 2 \quad(1 \cdot 7-136 \cdot 0)\end{array}$}} & \multicolumn{2}{|c|}{$(0 \mathrm{ca} v$ lco) } \\
\hline lectrical engineering & & & 0.8 & $(0 \cdot 2-3 \cdot 9)$ & & & & & 0.9 & $(0 \cdot 2-4 \cdot 3)$ \\
\hline $\begin{array}{l}\text { nipouilaing and marine } \\
\text { engineering }\end{array}$ & $2 \cdot 3$ & $(1 \cdot 0-5 \cdot 1)$ & 0.9 & $(0.4-1.9)$ & $2 \cdot 1$ & $(0.5-8.9)$ & 0.9 & $(0 \cdot 2-4 \cdot 2)$ & 0.3 & $(0 \cdot 1-1 \cdot 0)$ \\
\hline 'ehicles & 1.4 & $(0 \cdot 6-3 \cdot 0)$ & 0.9 & $(0.4-1.8)$ & $1 \cdot 0$ & $(0 \cdot 3-3 \cdot 7)$ & 0.9 & $(0 \cdot 2-3 \cdot 1)$ & $1 \cdot 3$ & $(0 \cdot 7-2 \cdot 5)$ \\
\hline Ietal goods nec & $2 \cdot 5$ & $(0 \cdot 9-7 \cdot 5)$ & $1 \cdot 4$ & $(0 \cdot 5-4 \cdot 5)$ & $2 \cdot 0$ & $(0 \cdot 2-22 \cdot 1)$ & 0.6 & $(0 \cdot 1-5 \cdot 1)$ & 0.5 & $(0 \cdot 1-1 \cdot 6)$ \\
\hline extiles & $2 \cdot 7$ & $(0.4-16 \cdot 0)$ & $1 \cdot 6$ & $(0 \cdot 3-8 \cdot 2)$ & \multirow{2}{*}{\multicolumn{2}{|c|}{$\begin{array}{l}(\text { ca } v 0 \mathrm{co}) \\
(0 \mathrm{ca} v 3 \mathrm{co})\end{array}$}} & \multirow{2}{*}{\multicolumn{2}{|c|}{$\begin{array}{l}(0 \mathrm{ca} v 2 \mathrm{co}) \\
(0 \mathrm{ca} v 2 \mathrm{co})\end{array}$}} & \multirow{2}{*}{\multicolumn{2}{|c|}{$\begin{array}{l}(0 \mathrm{ca} \vee 9 \mathrm{co}) \\
(0 \mathrm{ca} \vee 5 \mathrm{co})\end{array}$}} \\
\hline eather, leather goods, and fur & 1.6 & $(0 \cdot 1-18 \cdot 2)$ & 0.9 & $(0 \cdot 1-8 \cdot 0)$ & & & & & & \\
\hline lothing and footwear & & - & $2 \cdot 0$ & $(0 \cdot 2-22 \cdot 1)$ & & - & & - & & - \\
\hline iricks, pottery, glass, cement, etc & 0.4 & $(0 \cdot 0-3 \cdot 0)$ & 0.4 & $(0 \cdot 0-3 \cdot 1)$ & $4 \cdot 0$ & $(0 \cdot 3-64 \cdot 0)$ & \multirow{2}{*}{\multicolumn{2}{|c|}{$\begin{array}{l}(0 \mathrm{ca} v 2 \mathrm{co}) \\
(0 \mathrm{ca} \vee 2 \mathrm{co})\end{array}$}} & $1 \cdot 0$ & $(0 \cdot 3-3 \cdot 4)$ \\
\hline imber, furniture, etc & \multicolumn{2}{|c|}{$(2 \mathrm{ca} v 0 \mathrm{co})$} & \multicolumn{2}{|c|}{$(0 \mathrm{ca} v 5 \mathrm{co})$} & & - & & & 0.7 & $(0 \cdot 1-5 \cdot 5)$ \\
\hline 'aper, printing, and publishing & 3.9 & $(1 \cdot 4-10 \cdot 3)$ & $2 \cdot 2$ & $(1 \cdot 0-5 \cdot 1)$ & $2 \cdot 5$ & $(0 \cdot 4-15 \cdot 1)$ & $1 \cdot 3$ & $(0 \cdot 2-6 \cdot 9)$ & $1 \cdot 8$ & $(0 \cdot 3-9.9)$ \\
\hline ther manufacturing industries & $1 \cdot 3$ & $(0 \cdot 1-12 \cdot 8)$ & $1 . \overline{9}$ & $(0 \cdot 3-10 \cdot 4)$ & $1 \cdot 2$ & $(0 \cdot 1-11 \cdot 9)$ & $4 \cdot 0$ & $(0 \cdot 3-64 \cdot 0)$ & \multicolumn{2}{|c|}{$(0 \mathrm{ca} v 4 \mathrm{co})$} \\
\hline onstruction & 1.0 & $(0.6-1.6)$ & $1 \cdot 2$ & $(0 \cdot 7-1 \cdot 8)$ & $1 \cdot \overline{1}$ & $(0 \cdot 5-2 \cdot 3)$ & $1 \cdot 1$ & $(0 \cdot 6-2 \cdot 2)$ & $1 \cdot 2$ & $(0.8-1 \cdot 8)$ \\
\hline jas, electricity, and water & $2 \cdot 1$ & $(0 \cdot 9-4 \cdot 8)$ & 0.5 & $(0 \cdot 2-1 \cdot 8)$ & $8 \cdot 0$ & $(0 \cdot 7-88 \cdot 2)$ & 0.7 & $(0 \cdot 2-3 \cdot 2)$ & 0.8 & $(0 \cdot 3-2 \cdot 0)$ \\
\hline ransport and communication & $1 \cdot 1$ & $(0 \cdot 7-1 \cdot 7)$ & 0.6 & $(0.4-1.0)$ & $1 \cdot 6$ & $(0 \cdot 8-3 \cdot 1)$ & $1 \cdot 2$ & $(0 \cdot 7-2 \cdot 2)$ & $1 \cdot 0$ & $(0 \cdot 7-1 \cdot 5)$ \\
\hline Distributive trades & $1 \cdot 0$ & $(0 \cdot 5-1 \cdot 8)$ & $1 \cdot 3$ & $(0 \cdot 8-2 \cdot 0)$ & 0.8 & $(0 \cdot 3-2 \cdot 2)$ & 0.9 & $(0.4-1.8)$ & $1 \cdot 1$ & $(0 \cdot 7-1 \cdot 8)$ \\
\hline \multirow{5}{*}{$\begin{array}{l}\text { nsurance, banking, finance, and } \\
\text { business services } \\
\text { 'rofessional and scientific services } \\
\text { Uiscellaneous services } \\
\text { 'ublic administration and defence } \\
\text { Jnknown }\end{array}$} & & & & & & & & & & \\
\hline & $\begin{array}{l}2 \cdot 0 \\
0.9\end{array}$ & $\begin{array}{l}(0 \cdot 6-6 \cdot 6) \\
(0 \cdot 4-2 \cdot 0)\end{array}$ & $\begin{array}{l}0.8 \\
0.9\end{array}$ & $\begin{array}{l}(0 \cdot 3-2 \cdot 3) \\
(0 \cdot 5-1 \cdot 8)\end{array}$ & $\begin{array}{l}1 \cdot 7 \\
0.5\end{array}$ & $(0.4-6 \cdot 8)$ & $1 \cdot 3$ & $(0.3-6 \cdot 4)$ & $1 \cdot 2$ & $(0 \cdot 5-2 \cdot 7)$ \\
\hline & 0.6 & $\begin{array}{l}(0 \cdot 4-2 \cdot 0) \\
(0 \cdot 3-1 \cdot 4)\end{array}$ & $\begin{array}{l}0.9 \\
0.9\end{array}$ & $\begin{array}{l}(0.5-1 \cdot 8) \\
(0.5-1 \cdot 7)\end{array}$ & $\begin{array}{l}0.5 \\
1.0\end{array}$ & $\begin{array}{l}(0 \cdot 1-1 \cdot 9) \\
(0 \cdot 3-3 \cdot 9)\end{array}$ & $\begin{array}{l}1 \cdot 2 \\
1 \cdot 2\end{array}$ & $\begin{array}{l}(0.4-3.5) \\
(0.5-3.0)\end{array}$ & $\begin{array}{l}1.1 \\
0.6\end{array}$ & $\begin{array}{l}(0.6-1.9) \\
(0.3-1.2)\end{array}$ \\
\hline & 0.7 & $(0 \cdot 4-1 \cdot 4)$ & 1.6 & $(0.9-2 \cdot 7)$ & 0.5 & $(0 \cdot 1-1.6)$ & 0.6 & $(0.2-1.6)$ & $1 \cdot 2$ & $(0.7-1.8)$ \\
\hline & $0 \cdot 7$ & $(0 \cdot 5-1 \cdot 1)$ & 0.9 & $(0 \cdot 7-1 \cdot 2)$ & 0.6 & $(0 \cdot 3-1 \cdot 1)$ & $0 \cdot 8$ & $(0 \cdot 5-1 \cdot 2)$ & 0.7 & $(0.5-0.9)$ \\
\hline
\end{tabular}

When the relative risk was zero or infinite the numbers of cases and controls from the industry are given.

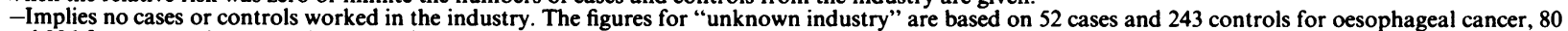
ind 336 for pancreatic cancer, 20 and 98 for melanoma, 31 and 146 for renal cancer, and 96 and 461 for brain tumours. 
Table 5 Associations between cancers and occupational orders: relative risks $(R R)$ and $95 \%$ confidence intervals (CI)

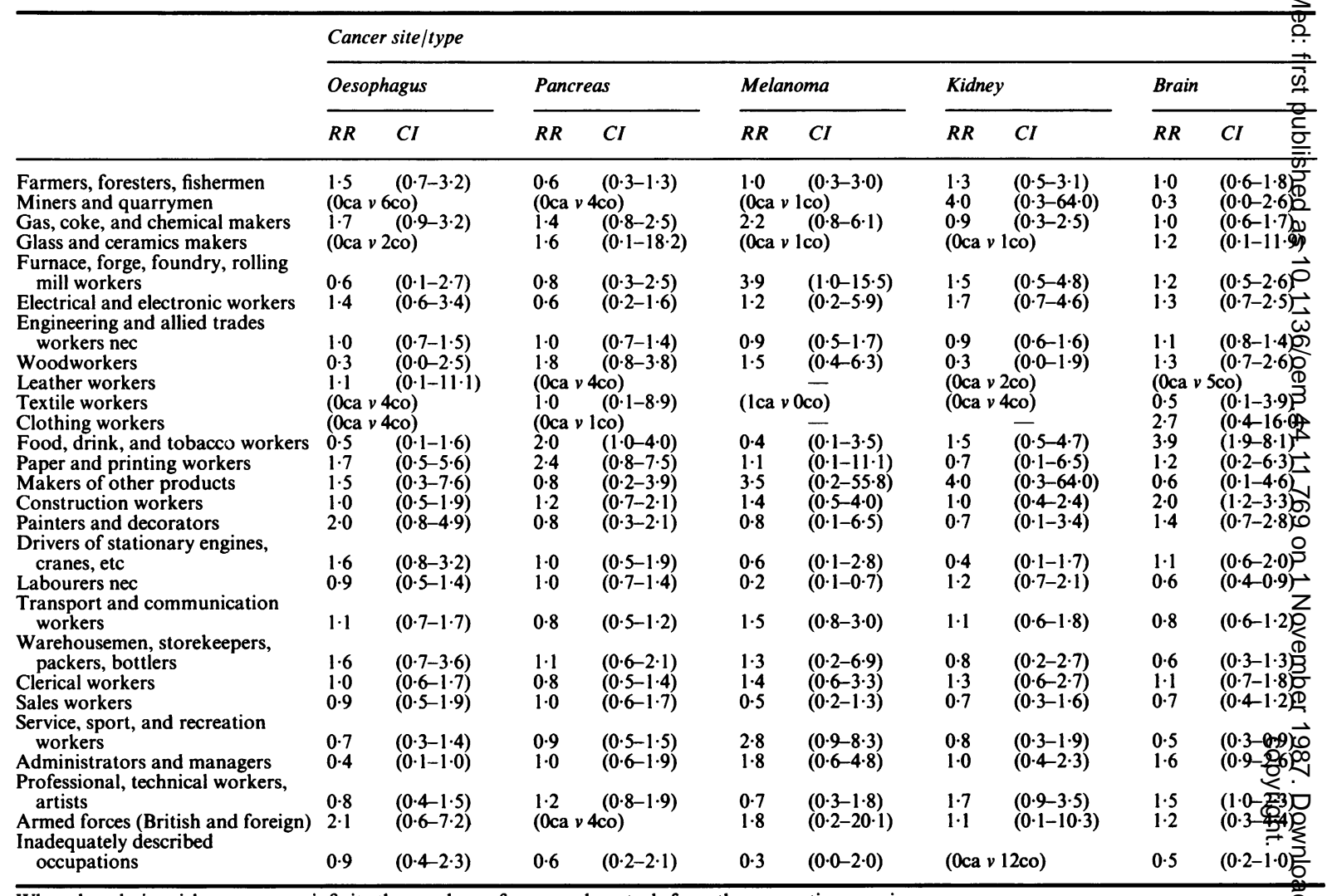

When the relative risk was zero or infinite the numbers of cases and controls from the occupation are given.

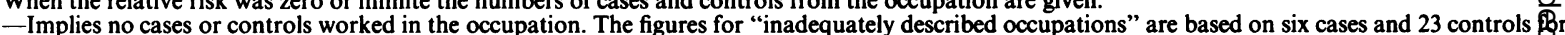
oesophageal cancer, three and 18 for pancreatic cancer, one and 13 for melanoma, 0 and 12 for renal cancer, and seven and 55 for brain tumours.

We then examined the more specific categories known as industrial and occupational units and where associations of interest emerged we looked to see whether the risk applied to particular combinations of occupation and industry. The salient features of this analysis are presented below for each cancer in turn.

\section{CANCER OF THE OESOPHAGUS}

Oesophageal cancer occurred more frequently than expected in the industrial order "paper, printing, and publishing" ( $R R=3.9$, CI 1.4-10.3). More detailed examination of the data, however, indicated that the eight cases were scattered throughout the industries in the group; manufacture of paper and board (2), production of packaging (2), newspaper printing (2), and other printing (2).

Ten cases worked in shipbuilding $(\mathbf{R} R=2 \cdot 3, \mathbf{C I}$ $1 \cdot 0-5 \cdot 1)$ but they were not concentrated in any one occupation.
Seven cases were employed in the electricity industry $(R R=3.4$, CI 1.2-9.3) but again they had held a? variety of different jobs.

An association with sea transport $(\mathrm{RR}=2 \cdot 5, \mathrm{CI} \stackrel{\oplus}{\stackrel{\Phi}{ }}$ 1.0-6.4) was due to a cluster of cases among both:seamen $(R R=3.2$, CI $0.9-11.9)$ and their officers 3 . $(\mathrm{RR}=2 \cdot 6, \mathrm{CI} 0 \cdot 7-9 \cdot 2)$.

There were no statistically significant associations with occupational orders but nine cases worked as 0 crane operators or slingers $(\mathrm{RR}=5 \cdot 8, \mathrm{CI} 2 \cdot 1-16 \cdot 3)$, including four in the iron and steel industry.

\section{CANCER OF THE PANCREAS}

Mortality from pancreatic cancer was high in the N industrial order paper, printing, and publishing (RRN $=2 \cdot 2$, CI $1 \cdot 0-5 \cdot 1)$ due largely to a cluster of five cases $\omega$ employed in the production of paper and board ( $R R$ $=4.8$, CI 1.3-18.1). Their occupations were traffic? controller, fitter (two cases), electrical plannings engineer, and machine tender. 
An association was also found with the industrial unit "dealing in coal, oil, etc" $(R R=7 \cdot 3, C I$ $1 \cdot 3-39.9$ ) but closer scrutiny of the cases' occupational records suggested that a common underlying cause was unlikely.

Among the occupational orders, "food, drink, and tobacco workers" showed the clearest excess of pancreatic cancer $(\mathrm{RR}=2 \cdot 0, \mathrm{CI} 1 \cdot 0-4 \cdot 0)$. Five cases $(v$ seven controls) were butchers and five cases ( $v$ seven controls) had worked in fish shops or as fish filleters.

A high relative risk was found for "packers, labellers, and related workers" ( $R R=5 \cdot 1, \mathrm{CI} 1 \cdot 1-22 \cdot 9)$ but the industrial activities of the cases had little in common.

\section{CUTANEOUS MELANOMA}

An association with the industrial order "coal and petroleum products" ( $R R=8.0, \mathrm{CI} 1.5-43.7)$ arose from a small cluster of deaths among men employed in mineral oil refineries. The occupations of the four cases were process worker/blender, engineer, security officer, and clerk of works.

Two other industries showed associations with melanoma-road haulage contracting $(R R=15 \cdot 2$, CI 1.7-136.0) and port and inland water transport $(\mathrm{RR}=4 \cdot 1, \mathrm{CI} 1 \cdot 1-15 \cdot 5)$ but the occupations of the cases did not point to an underlying cause.

An increased risk of melanoma in "furnace, forge, foundry, and rolling mill workers" ( $R R=3.9, C I$ $1 \cdot 0-15 \cdot 5)$ could not be attributed to an excess in any one occupation within the order.

\section{CANCER OF THE KIDNEY}

Four cases worked in "electrical engineering" $(\mathbf{R} R=$ $15 \cdot 2$, CI 1.7-136.0) but came from various industries within the group.

No occupational orders were significantly associated with renal cancer. There was an excess of the tumour among electricians $(R R=2 \cdot 9, \mathrm{CI} 1 \cdot 0-8 \cdot 3)$ but not among other electrical and electronic workers. The six electricians with cancer of the kidney came from various industries but none was employed in electrical engineering.

Six deaths from renal cancer occurred in teachers $(\mathrm{RR}=5 \cdot 2$, CI 1.5-18.6).

\section{CANCER OF THE BRAIN}

Two industrial orders showed a significant excess of brain cancer. The increased risk in coal and petroleum products $(\mathrm{RR}=3 \cdot 5, \mathrm{CI} 1 \cdot 5-8 \cdot 1)$ applied to both "coke ovens and manufactured fuel" (two cases $v$ no controls) and mineral oil refining $(\mathrm{RR}=2.9, \mathrm{CI}$ $1 \cdot 2-7 \cdot 0$ ). Four cases ( $v$ four controls) worked as process operators in refineries. In addition, three cases were employed in wholesale petroleum distribution $(R R=10 \cdot 3$, CI 1.0-100.8).
The association with food, drink, and tobacco arose from an excess of brain tumours in "bacon curing, meat, and fish products" $(\mathrm{RR}=9.7, \mathrm{CI}$ 2.6-36.8). In particular, seven cases worked in the fish processing and frozen food industry - two filleters, two shift supervisors, one hygiene worker, one wholesale fish merchant, and an accounts clerk.

This partially explains the high rate of brain cancer in the occupational order food, drink, and tobacco workers ( $R R=3.9$, CI 1.9-8.1), although there was also an excess of brain tumours among bakers (three cases $v$ no controls) and butchers $(\mathrm{RR}=1.9, \mathrm{CI}$ $0 \cdot 3-10 \cdot 4)$.

"Construction workers" had a relative risk of $2 \cdot 0$ (CI 1.2-3.3) for brain cancer, the association being strongest for bricklayers $(\mathrm{RR}=3.8, \mathrm{CI} 1 \cdot 6-9.0)$ and bricklayers' labourers $(R R=3 \cdot 7, C I 1 \cdot 3-10 \cdot 7)$.

Other isolated findings were an excess of brain tumours in "managers nec" $(R R=3.0, C I 1 \cdot 4-6 \cdot 2)$ and "technologists nec" $(\mathrm{RR}=3 \cdot 6, \mathrm{CI} 1 \cdot 3-10 \cdot 3)$. In neither instance did the industrial activity of the cases suggest an occupational cause for the association.

The results of the analysis using the job-exposure matrix are summarised in table 6 . Where positive associations emerged, risks were examined in relation to three grades of potential exposure. Only one association was both statistically significant and exhibited a dose response relation. The risk of melanoma in jobs entailing possible exposure to lead and lead compounds (as compared with unexposed jobs) was 1.8 (CI 1.0-3.4). Of the 16 cases classed by the matrix as having possible contact with lead, seven were in low exposure jobs $(R R=1 \cdot 3)$, eight in the moderate exposure category $(R R=2 \cdot 2)$, and one, a compositor, was deemed to have potentially high exposure $(R R=4 \cdot 0)$.

\section{Discussion}

This survey is subject to certain limitations that are common to all analyses of occupational mortality based on death certificates. One weakness is the inaccuracy of certified causes of death, ${ }^{9}$ although the frequency of such errors should have been reduced by our concentration on mortality at young ages when clinical investigation is likely to be more thorough.

A greater shortcoming is the inaccuracy and incompleteness of occupational data obtained from death certificates. In England and Wales only the most recent fulltime job is registered and even that may not be adequately described. By adopting the case-control approach we avoided the biases that occur when different sources of occupational information (death certificates and census) are used to derive the numerator and denominator of death 
Magnani, Coggon, Osmond, Acheson $\stackrel{\complement}{\bar{z}}$

Table 6 Associations between cancer and potential occupational exposures: relative risks (RR) and $95 \%$ confidence intervals $(C I)$

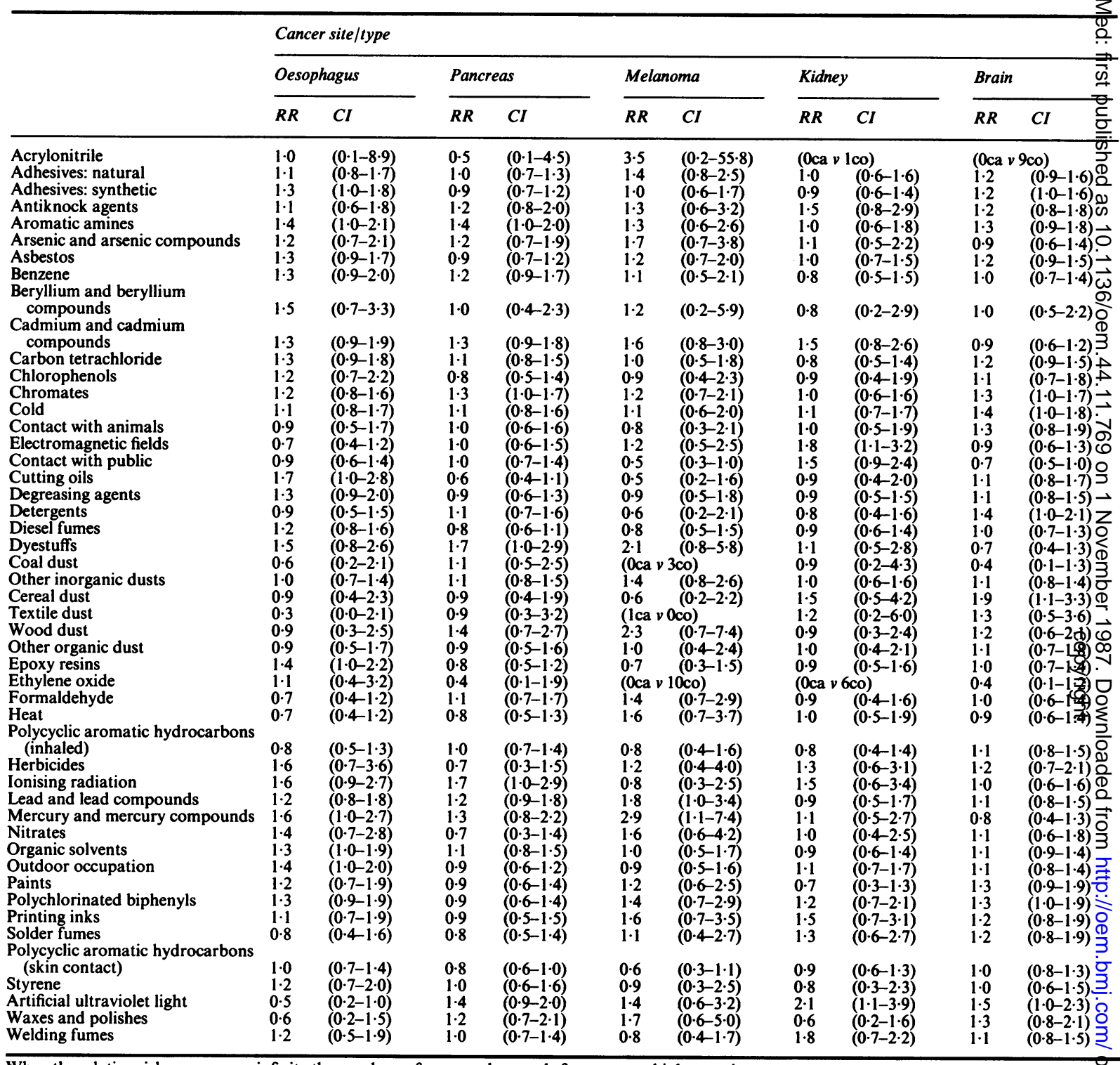

When the relative risk was zero or infinite the numbers of cases and controls from exposed jobs are given.

rates. $^{1011}$ Nevertheless, the fact that occupational histories were available more often for cases than controls is an indication that bias was still present. The effect of the bias will have been to inflate risk estimates somewhat. On the other hand, hazards in industries with a high turnover of labour may have been missed because victims were working in other jobs at the time they died.

No information was available about potential con- founding factors, in particular alcohol and smoking. The high rate of oesophageal cancer among merchant $N$ seamen, for example, may be explained by above average consumption of tobacco and alcohol.

Further difficulty in interpretation arises from the large number of potential disease associations that were examined. Of necessity our report is selective, and we have restricted our attention to positive associations that were statistically significant at a $5 \%$ level 
and based on more than three cases. Inevitably, these will include many chance associations, and evaluation requires consideration of data from other studies and the biological plausibility of suggested hazards. The capacity to examine information about occupation in conjunction with industry was therefore an advantage.

By concentrating on a limited geographical area and combining data from 20 years we could look at local industries in a way not possible using national statistics. Men employed in the fish processing and frozen food industries (fish is one of the major frozen food products in the study area) would contribute to several occupational units in the Registrar General's analyses of occupational mortality, and the effects of any hazard would be diluted by the inclusion of workers from other food industries in the same categories. The risks of pancreatic and brain cancer found in this group are therefore of particular interest and despite the lack of an obvious carcinogenic mechanism warrant further investigation.

Mineral oil refining is another local industry and was found in association with both melanoma and brain cancer. Unlike the processing of fish and frozen food, the petrochemical industry has been extensively investigated in the past. A risk of melanoma in refinery workers has been reported in one previous study ${ }^{12}$ and an increased incidence of brain cancer in four investigations. ${ }^{13-16}$ In a recent review Alderson pooled data from ten cohort studies of the industry and derived a relative risk of $1 \cdot 16$ for cancer of the brain with a $95 \%$ confidence interval $1 \cdot 0-1 \cdot 3$. $^{1}$

We chose our study area because it included important centres of chemical manufacture and many of the known occupational carcinogens are industrial chemicals. As things turned out, however, the survey did not point to any risks in the chemical industry. This may be because there are no major hazards, or it is possible that even within the limited population studied the effects of a carcinogen have been masked by a large majority of chemical workers not exposed to the compound.

Several of the associations demonstrated concern occupations with a more uniform geographical distribution, and for looking at these jobs our method offers no advantage over larger national analyses of occupational mortality. Thus the increased incidence of renal cancer in teachers and of brain cancer in bricklayers and their labourers must be weighed against the absence of any clear risk in the 1971 OPCS Decennial Supplement on Occupational Mortality. ${ }^{11}$ On the other hand, the excess of pancreatic cancer in butchers is supported by an SMR of 156. A cohort study of butchers and slaughtermen is currently being carried out by the Medical Research Council and should provide firmer evidence for or against a hazard.
In addition to the positive associations already discussed several occupations and industries were found to have significantly low risks of cancer.We have not dwelt on these, however, as it seems unlikely that they represent a direct protective effect of the working environment. A few negative associations-for example, the low incidence of brain cancer in labourers $(R R=0.6, C I 0.4-0.9)-$ may be attributable to correlates of social class, but most are probably spurious.

Application of the job-exposure matrix added little to the analysis. This may be because there are no important associations between the agents included in the matrix and the cancers studied, but the uncertainty with which exposures can be inferred from the limited occupational information recorded on death certificates was a major constraint. For example, among the cases classed as potentially exposed to lead were several chemical process workers and refinery workers, but without more detailed job descriptions it is impossible to be sure which, if any, of these men actually had contact with lead. We are unaware of any previous studies linking lead compounds with melanoma and the association in our survey may well have occurred by chance.

The most interesting findings of the study are those relating to the processing of fish and frozen foods and to mineral oil refining. Whether the demonstrated associations have a biological basis will only become clear with further research. We think, however, that our observations show the potential value of this analytical approach as an adjunct to other methods of examining occupational mortality.

We thank the Office of Population Censuses and Surveys for providing us with the death certificates, Paul Winter who helped with the computing, and Dr A Ward Gardner who helped with the coding of occupations.

Dr C Magnani carried out this work during the tenure of a research training fellowship awarded by the International Agency for Research on Cancer.

\section{References}

1 Alderson M. Occupational cancer. London: Butterworth, 1986.

2 Schottenfeld D, Fraumeni JF, eds. Cancer epidemiology and prevention. Philadelphia: WB Saunders, 1982.

3 Merletti F, Hesletine E, Saracci R, et al. Target organs for carcinogenicity of chemicals and industrial exposures in humans: a review of results in the IARC monographs on the evaluation of the carcinogenic risk of chemicals to humans. Cancer Res 1984;44:2244-50.

4 Weiss W, Boucot KR. The respiratory effects of chloromethyl methyl ether. JAMA 1975;234:1139-42.

5 General Register Office. Classification of occupations (1966). London: HMSO, 1966.

6 Central Statistical Office. Standard industrial classification. London: HMSO, 1968. 
7 Pannett B, Coggon D, Acheson ED. A job-exposure matrix for use in population based studies in England and Wales. Br J Ind Med 1985;42:777-83.

8 Breslow NE, Day NE. Statistical methods in cancer research. Vol 1. The analysis of case-control studies. Lyon: International Agency for Research on Cancer, 1980.

9 Heasman MA, Lipworth L. Accuracy of certification of cause of death. London: HMSO, 1966. (General Registrar Office studies on medical and population subjects No 20.)

10 Alderson MR. Some sources of error in British occupational mortality data. Br J Ind Med 1972;29:245-54.

11 Office of Population Censuses and Surveys. Occupational mortality 1970-72. Decennial supplement for England and Wales. London: HMSO, 1978. (Series DS No 1.)
12 Rushton L, Alderson MR. An epidemiological survey of eight oif refineries in Britain. Br J Ind Med 1981;38:225-34.

13 Theriault G, Goulet L. A mortality study of oil refinery workers $\stackrel{\mathbb{D}}{\Omega}$ J Occup Med 1979;21:367-70.

14 Waxweiler RJ, Alexander V, Leffingwell SS, Haring M, Lloyd JW. Mortality from brain tumour.and other causes in a cohorr of petrochemical workers. JNCI 1983;70:75-81.

15 Thomas TL, Waxweiler RJ, Crandall MS, et al. Brain cancer음 among OCAW members in three Texas oil refineries. Ann $N$ Y Acad Sci 1982;381:120-9.

16 Nicholson WJ, Seidman H, Selikoff IJ, et al. Brain tumours among operating engineers in the chemical and petrochemica? industry in Texas and Louisiana. Ann NY Acad Sci 1982;381:172-80.

\section{Correction}

An industry wide mortality study of chemical workers occupationally exposed to benzene. II Dose response analyses (June 1987)

The author regrets that an incorrect table was submitted. Table 14 (p. 391) should read as follows:

Table 14 Mantel-Haenszel relative risks and extension chi-squares for lymphatic and haematopoietic cancer, leukaemia, non-Hodgkin's lymphoma, and non-Hodgkin's lymphopoietic cancer by maximum peak occupational exposure to benzene, adjusted for age and race

\begin{tabular}{|c|c|c|c|c|c|}
\hline $\begin{array}{l}\text { Cause of death } \\
(8 t h I C D)\end{array}$ & $\begin{array}{l}\text { Maximum peak exposure } \\
\text { (ppm) }\end{array}$ & $\begin{array}{l}\text { Observed } \\
\text { deaths }\end{array}$ & $\begin{array}{l}\text { Relative } \\
\text { risk }\end{array}$ & Chi-square & p Value \\
\hline $\begin{array}{l}\text { Lymphatic and haematopoietic } \\
\text { cancer }(200-209)\end{array}$ & $\begin{array}{l}\text { Non-exposed } \\
<25 \\
25-100 \\
\geqslant 100\end{array}$ & $\begin{array}{l}3 \\
4 \\
7 \\
8\end{array}$ & $\begin{array}{l}1.00 \\
3.38 \\
2.96 \\
3.01\end{array}$ & $2 \cdot 10$ & 0.148 \\
\hline $\begin{array}{l}\text { Leukaemia and aleukaemia } \\
\quad(204-207)\end{array}$ & $\begin{array}{l}\text { Non-exposed } \\
<25 \\
25-100 \\
\geqslant 100\end{array}$ & $\begin{array}{l}0 \\
1 \\
2 \\
4\end{array}$ & Undefined & $2 \cdot 91$ & 0.088 \\
\hline $\begin{array}{l}\text { Non-Hodgkin's lymphoma } \\
\quad(200,202,203)\end{array}$ & $\begin{array}{l}\text { Non-exposed } \\
<25 \\
25-100 \\
\geqslant 100\end{array}$ & $\begin{array}{l}2 \\
3 \\
4 \\
3\end{array}$ & $\begin{array}{l}1.00 \\
3.44 \\
1.98 \\
1.57\end{array}$ & 0.06 & 0.807 \\
\hline $\begin{array}{l}\text { Non-Hodgkin's lymphopoietic } \\
\text { cancer }(200,202-207)\end{array}$ & $\begin{array}{l}\text { Non-exposed } \\
<25 \\
25-100 \\
\geqslant 100\end{array}$ & $\begin{array}{l}2 \\
4 \\
6 \\
7\end{array}$ & $\begin{array}{l}1 \cdot 00 \\
4 \cdot 62 \\
3 \cdot 32 \\
3 \cdot 89\end{array}$ & 1.95 & $0 \cdot 163$ \\
\hline
\end{tabular}

(Lymphatic and haematopoietic cancer includes non-Hodgkin's lymphoma, Hodgkin's disease, and leukaemia.) 